\title{
The World in Paris and Ireland too: The French Diplomacy of Sinn Féin, 1919-1921
}

\section{Pierre Ranger}

\section{Q OpenEdition \\ 1 Journals}

\section{Electronic version}

URL: http://journals.openedition.org/etudesirlandaises/2333

DOI: 10.4000/etudesirlandaises. 2333

ISSN: 2259-8863

\section{Publisher}

Presses universitaires de Rennes

\section{Printed version}

Date of publication: 30 December 2011

Number of pages: $39-57$

ISSN: 0183-973X

\section{Electronic reference}

Pierre Ranger, "The World in Paris and Ireland too: The French Diplomacy of Sinn Féin, 1919-1921 », Études irlandaises [Online], 36-2 | 2011, Online since 30 September 2013, connection on 02 May 2019. URL : http://journals.openedition.org/etudesirlandaises/2333; DOI : 10.4000/etudesirlandaises.2333

This text was automatically generated on 2 May 2019.

(c) Presses universitaires de Rennes 


\section{The World in Paris and Ireland too: The French Diplomacy of Sinn Féin, 1919-1921}

Pierre Ranger

1 While the first delegates to the Peace Conference were arriving in Paris during the winter of 1918-1919, Europe had just woken up to its own tragedy. The First World War killed millions of soldiers and the economic, social and political toll was unprecedented. Only Spain, Switzerland, the Netherlands and the Scandinavian countries had retained their neutrality and were spared. After a conflict of this magnitude, it was unavoidable that the map of Europe would be redrawn. In particular, a safety net had to be created to keep newly born communist Russia under control. As far as the French were concerned, their compulsive obsession was to gain protection from Germany and to squeeze the country financially; in short to make it responsible and therefore to make it pay. The rise of new countries and of new national demands emanating from the crumbling Austro-Hungarian Empire added an enormous complexity to the task faced by the victorious world leaders. Regarding the future of Germany, the result of these long negotiations is known as the Treaty of Versailles, signed on June 28. Quite logically, the very beginning of the 1920s was partly overshadowed by the difficulties to implement the decisions imposed by the treaty, in particular the "reparations" owed by Germany to France. Diplomatic tensions did occur between France and Great Britain, which was reluctant to impose on Germany the payment in full of the reparations. Of course this was to the delight of the Irish envoys in Paris, the men under our scrutiny in this article.

2 The Irish context had its own particular dynamic during the months of the Peace Conference negotiations and the tense diplomatic years that followed. 1919 signalled the start of what is remembered as the Irish revolution (though historians also use 1912 as a starting point, the year the Home Rule crisis began). It was marked in December 1921 by the signature of the Anglo-Irish treaty that led to the creation of the Irish Free State, followed by two years of civil war. But this article leaves aside the Irish-British context and demonstrates that many among Sinn Féin's leadership kept in mind the extreme 
importance of the international community to achieve a degree of independence. To send a delegation of Irish representatives to the Peace Conference was very important not only politically but also symbolically. European opinions were scrutinized, the governments contacted. The reactions of the continental public to Sinn Féin's victory and the formation of the Dáil became an important matter of concern. A propaganda war had to be won to ensure that Ireland's first months of existence as a free nation would allow the establishment of Irish diplomacy. This was one of the first prerequisites of the recognition of Irish national sovereignty by the international community.

In this context, France and French public opinion became major objectives of Sinn Féin's strategy. Paris hosted the Peace conference. Therefore, relations with the French government and, most importantly, the French press, were relatively easy to organise. Moreover, France was placed in a difficult situation by Great Britain during the negotiations and in the following years, with the British government often challenging French demands on the payment of war reparations by Germany. This could lead the Irish envoys to believe that French opinion would grow increasingly impatient with its ally in the war, and return to previous Anglophobic attitudes. Furthermore, France was a republic, whose image as an ideological model for many Irish republicans and as an ally of Ireland against Great Britain played a major role in the development of an Irish separatist narrative during the $19^{\text {th }}$ century; a rhetoric that did not only look at Anglo-Irish relations to define the place of Ireland in the world, but also to continental Europe. Of course, the development of stronger links with Germany and the 1916 Rising had altered these representations of Franco-Irish connections. However, defeated Germany could not be of much use in 1919. As a consequence, the French dimension of the diplomacy of Irish delegates during the Peace Conference was concerned with pragmatic considerations accompanied by a romantic image of republican France and of its public opinion, always prompt to support oppressed nationalities, more particularly so when the oppressor was English. At least this was the France that lived in Irish nationalist memories; and this in spite of past governmental policies that could have altered this representation, with the signing of the Entente Cordiale in 1904 and the implementation of the Law of the Separation of the Churches and the State in 1905.

Quite independently from the nature of the Irish representations of France until the beginning of the $20^{\text {th }}$ century, to limit this analysis to one particular country will provide a better understanding of the embryonic structure of Irish diplomacy, its dynamics, objectives, methods and results. This article will show the great importance which the development of an Irish diplomacy held for the affirmation of the country's independence and the extreme difficulties facing young and largely inexperienced diplomats; in short, it will analyse the implementation of a pragmatic Irish diplomatic policy which faced the realities of the raison d'État.

\section{Ireland and France during the First World War ${ }^{1}$}

5 Despite the efforts of a radical fringe of nationalist leaders, Ireland did not escape the massacre of the First World War, with 210,000 soldiers sent into the trenches, of whom an estimate of $35,000^{2}$ did not make it back, even though the precise figure is subject to debate. Therefore, it is essential to study the influence of the war on the Irish political context if we are to understand properly the establishment of Irish diplomacy in the 1920s and its relations with France. As David Fitzpatrick explained, the European conflict 
is at least as important in understanding the radicalisation of Irish political life as the the 1916 Easter Rising ${ }^{3}$. Ireland's story during the First World War is one of transition, of failure and of rebirth. Central to these three phenomena were Europe and France, present in pain as well as in victory.

The Irish political context before and at the very start of the war is well known. There was the apparent march towards civil conflict in 1912 and 1913, marked by the creation of the unionist Ulster Volunteer Force and of the nationalist Irish Volunteers. This was put to a halt by the outbreak of the war and the decision announced by John Redmond in his Woodenbridge speech to support the allies' war effort. The split in the Irish Volunteers followed immediately, resulting in a division between the Irish Volunteers, who opposed Redmond's decision and were led by Eoin MacNeill, and the National Volunteers, who were under the leadership of John Redmond.

7 At the French Foreign Office in Paris, the Irish situation was placed under close scrutiny. An explosive Irish political situation could weaken Great Britain, destabilise the Western Front and endanger recruitment in Ireland. News of contacts made by some Irish republicans with Germany did nothing to ease these fears. Yet, for France, things seemed to have started in a relatively satisfying manner in Ireland. John Redmond, in his Woodenbridge speech, linked Ireland's destiny with that of France ${ }^{4}$. Along with a more traditional rhetoric on the fate of small nations, which allowed Redmond to associate his support for the allies with the fate of small and Catholic Belgium, he mentioned France in particular. By using the theme of Celtic identity, Redmond wanted to make the war the symbol of pan-Celtic solidarity. This was the occasion to demonstrate the values of a Celtic "race" led by Ireland and France; a common identity articulated over the preceding decades by the promoters of what Matthew Kelly called cultural separatism ${ }^{5}$. In fact, throughout the war, Redmond and the newspapers who supported his action, such as the Freeman's Journal, associated with and encouraged the French war effort. In doing so, the newspaper was supporting the allies without emphasising the role of Great Britain. Even before the Woodenbridge speech, the Freeman had demonstrated this sort of approach ${ }^{6}$. This approach becomes clear when it is compared with the propaganda of the unionist press, where the French and British war efforts were linked ${ }^{7}$.

Despite the good-will of pro-ally Irish newspapers, a growing awareness by the French government of anti-allies declarations can be detected. In December 1914, in a memorandum on the state of Irish opinion, Thomas Power O'Connor, who was working in constant contact with the French, pointed out the work of a little group of radicals using French anticlericalism to discredit the French war effort ${ }^{8}$. The importance of the Catholic Church in Ireland was well enough known in France to force the government to take action. This appeared all the more urgent since the Irish clergy, while supporting the allies, was aware of Germany's good relations with the Vatican and of the fact that the Germans received the support of some cardinals of the Curia ${ }^{9}$, this at a time when recruitment was starting to slow down in Ireland ${ }^{10}$.

At the beginning of 1915, the French government decided to tackle the problem by inviting an Irish delegation to Paris, between 30 April and 1 May. The declared objective was to renew the friendly feelings of Irish Catholics towards France. The delegation was mostly composed of members of the Ancient Order of Hibernians led by Joseph Devlin. The President of the Republic, Raymond Poincaré, and the President of the Council, the anticlerical René Viviani, were present to welcome them. Speeches were made, with Thomas O'Connor reflecting on the Celtic blood that French and Irish soldiers had shed in 
past battles against a common foe ${ }^{11}$. Religious affairs were left to Devlin who highlighted the fact that priests had fought in the trenches and showed himself "very touched by the precious token of Catholic sympathy that was given". Devlin did not omit to conclude with the advent of a "new France ${ }^{12}$ ", to underline the renewal of religious practice in the country since the beginning of the war. For the time being, French anticlericalism had to be buried under declarations of renewed Franco-Irish Catholic bonds. In the months following the visit, this new France, cleansed from all her amoral and godless actions, was promoted in the Freeman's Journal ${ }^{13}$.

10 Faced with this pro-allies agitation, nationalists opposed to the sending of Irish troops to the continent had to react. In fact, through a succession of very small newspapers ${ }^{14}$, the anti-allies camp took the time to develop quite a complex propaganda in the first two years of the war. It could have been expected that, as an answer to the Freeman propaganda, these newspapers would have emphasised France's recent past of anticlericalism. But the manner in which Irish separatists, in particular Arthur Griffith, addressed the question of French involvement in the war was rather complex and uneasy. This is not to say that France was never targeted by the anti-allies press. It was, and sometimes quite aggressively so ${ }^{15}$. However, it is also important to acknowledge the existence of an approach that was not one sided, in particular during the first two years of the war. To understand this attitude, it is necessary to summarize briefly what France and its revolutionary myth meant to Irish separatism throughout the $19^{\text {th }}$ century.

11 Ever since French soldiers landed at Killala in 1798 up until the beginning of the $20^{\text {th }}$ century, France, in the Irish separatist mind, was the defender of oppressed nationalities and the first ally of Ireland. Contrary to what Marianne Elliot affirmed ${ }^{16}$, the remembrance of this event was rooted very deeply in Irish nationalist memory, making 1798 a Franco-Irish lieu de mémoire ${ }^{17}$. It is not possible here to trace every detail of the dynamic of this phenomenon. Suffice it to say here that what could be called a "mythe français" was developed in the 1840s largely by the Young Ireland movement, which was itself strongly influenced by the February 1848 revolution in Paris. It was perpetuated during the second half of the $19^{\text {th }}$ century, and insisted on the permanent possibility of a Franco-British war, in particular in view of the increasing colonial tensions at the end of the $19^{\text {th }}$ century. This myth was developed independently from the French interior context and indeed from French policy toward Ireland itself. It only reflected Ireland's national debates. It used the representation of a revolutionary France, remembered after 1798, as an ideological model, but also a source of inspiration and pride. In fact, the few Irish victories against English armies were won alongside French troops, from Fontenoy to the Napoleonic campaigns ${ }^{18}$. For Irish separatists who tended to have an obsession with past events as a source of explanations, lessons and justifications for present actions, it was rather difficult to ignore such a historical presence during the first two years of the First World War, particularly when pro-allies newspapers used it continuously.

of course, there was not a perfect uniformity of tone between these different small antiallies publications. The Spark, for example, did not devote much attention to France and focused most of its propaganda around the necessity of an alliance with Germany. However, in particular in the case of Griffith's newspapers, three distinct rhetorical tactics were used to deal with the role of France in the war. Firstly, to target French anticlericalism, it developed the contrast between an amoral French leadership and the sober and brave French people ${ }^{19}$. It was a way of responding to the propaganda led by the Freeman's Journal without damaging what the French nation, the French people had 
always represented in Irish separatist mythology. Another way to address the "French question" was simply to ignore that France was even involved in the war. But the most common solution chosen was to present France as the victim of a war mostly fabricated by the English - as Eire-Ireland suggested ${ }^{20}$. According to this view, France was not an aggressor, as opposed to Great Britain or Russia. As early as 1904, when France signed the Entente Cordiale with Great Britain, Griffith presented the result of the agreement as the seduction of naïve French leaders by "perfidious Albion". The war itself was seen as a perfect opportunity to expose English machinations. For example, the sacrifice of French soldiers on the field was often contrasted with an alleged English wait-and-see policy ${ }^{21}$. And while the war was taking hold of Europe, some Irish separatists insisted on supposed tensions between French and English soldiers ${ }^{22}$. After several years of blindness, France was finally waking up to the realities of its alliance with the Devil.

The aftermath of 1916 largely changed this approach. First of all, most of the small antiallies newspapers did not survive the introduction of state censorship after the rising. Griffith's abilities alone allowed Nationality to survive until the end of the war. In the last two years of the war, this newspaper clearly dropped all caution when addressing the French involvement in the war. This evolution of tone was also expressed in the Catholic Bulletin. Having been relatively friendly towards France at the start of the war, after the rising it refuted France's right to reclaim Alsace-Lorraine ${ }^{23}$, which it had regarded as a legitimate demand until then. We may conclude that one myth had replaced another as the French myth was killed by the newly constructed memory of Pearse, Connolly and MacBride. For this reason, Irish diplomacy after the war did not espouse the romantic vision of France as the oldest ally of Irish freedom. In spite of this, pragmatism was still an alien phenomenon to many inexperienced Irish diplomats, when Paris hosted what was the hope of all the emerging nations of Europe in 1919.

\section{The difficult beginnings of Irish diplomacy in Paris}

During the first six months of 1919, until the signing of the Versailles Treaty on 28 June, government representatives in the council of the big Four (France, Great Britain, Italy and the United States) met continuously. Germany was not invited to these discussions but was presented with the decisions concerning its own political and economic future. These men also decided on the creation of new borders with the delegates of more than 30 countries who met each other while staying in Paris for the duration of the negotiations. Of these delegates, some had come to ask the victorious nations to acknowledge their right to create an independent country. Their hopes were high, but if these small nationalities with their claims had not previously been part of one of the defeated powers, their chances of success were slim. This was the rather difficult position faced by the unofficial delegation whose activity will be scrutinised in the next few pages: Ireland.

15 Setting up a non-official government was not an easy task for the Dáil's representatives. Each strategic post had to be filled with young people who were energetic and talented, but for the most part inexperienced. Sinn Féin's objective was to make the British administration obsolete. There was one domain where the Sinn Féin leaders' lack of experience was blatant: diplomacy. Nevertheless, de Valera counted upon the positive results of the Sinn Féin delegation in Paris, which he believed could gain international recognition, if not from all the allies, then at least from the United States. De Valera and 
the other leaders of Sinn Féin also wished to neutralize the influence of British diplomacy ${ }^{24}$. Seán T. O'Kelly was the first Sinn Féin representative to depart for the French capital. He was a passionate cultural nationalist who could express himself perfectly in French. He rapidly secured George Gavan Duffy's help. Our analysis will focus on the latter's work. If O'Kelly oversaw the diplomatic activities and the Dáil's propaganda across Europe, and was often based in Paris, Duffy's linguistic competence made him the man in charge of the propaganda activities in France. The two men were briefly joined by Erskine Childers, a former British officer who had been won over to the Irish republican cause.

During the first weeks, the situation did not appear favourable. The Irish delegates were not official guests at the Peace conference, and therefore had to content themselves with the status of observers. This situation largely limited any real possibility of governmental support for Irish independence, because, as Lloyd George explained, Treaty-makers in Paris would only acknowledge the existence of liberated nationalities that had "overstepped the bounds of self-determination ${ }^{25}$ ". For the time being, such was not the case with Ireland. Woodrow Wilson, Sinn Féin's main source of hope as the president of the United States, did not even consider that Irish national claims were justified since Irish people already lived in a democratic country ${ }^{26}$. Back in Europe, the countries which gained independence during the Peace Conference were generally of the highest strategic importance. This was the case with Poland and Czechoslovakia which represented important allies against Bolshevik Russia and Germany, particularly for the French. For France, an alliance between these two countries and Romania could compensate for the loss of Russia as an ally in 1917. Ireland had nothing of this sort to offer, and Clémenceau maintained points of view that were not much in favour of the Irish claims ${ }^{27}$. Firstly, he wanted to keep on the best possible terms with Great Britain, his best ally during the negotiations, and wanted to ensure the protection of French territory against Germany. Secondly, French governmental circles remembered the 1916 rising, and none too sympathetically. The impossible situation in which the Sinn Féin envoys found themselves when dealing with France was summed up by André Tardieu, commissioner for Franco-American affairs. His published work, La Paix, was translated in 1921 under the title The Truth about the Treaty; he divulged his views on the Irish issue in this book:

And how can I avoid the Irish question? [...] during the war the Sinn-Féiners harboured and supplied German submarines and took German gold to pay for Casement's treason. Here too Great Britain needed France ${ }^{28}$.

These inauspicious beginnings of Sinn Féin's diplomatic efforts in Paris were clearly demonstrated by Gavan Duffy in his first correspondence. In a report from 22 June 1919 for example, he explained:

The French side of the work here has been most disappointing; the French press and politicians are very anxious to keep on good terms with England and they are so afraid of the Germans that I think this policy will be kept up [...] The only way to effective propaganda is to get personal introductions to well-known and influential people and to get French writers interested in this way ${ }^{29}$.

Duffy's decision to develop a specific policy towards journalists and influential writers became a reality during the year 1920. But for the time being, he could do no more than observe the failure of his efforts, as there was a strong willingness within French opinion to maintain good relations with Great Britain in order to see Germany pay the "reparations" in full. In several letters Gavan Duffy repeated the difficulties he had to make contact with respectable newspapers and influential journalists. His main target throughout his stay in France was Le Temps, which Childers was asked to infiltrate. But 
the newspaper seemed very reluctant to listen to Duffy's claim, due to the privileged relation it entertained with the French Foreign Office. In a report dated 29 July, Duffy noted: "The paper is quite the most influential in France and its foreign editor, M. Herbette, is scrupulously careful to act under direct orders from the Foreign office ${ }^{30}$." Quite interestingly, we should add that no matter how elusive the press and the French authorities were, this did not stop them from trying to promote the image of France in Ireland. We can take the example of a letter dated 6 February 1919, sent by the publishing company Bloud and Gay to the French consul in Dublin, Alfred Blanche. According to this letter, the publisher had been given the responsibility by the consul to "make France better known" and to "shield Ireland from German influence ${ }^{31}$ ".

No major evolution was noticed during the second half of 1919. Following the signing of the Versailles Treaty, the context was more favourable, since France had obtained what it wanted from Germany, and did not need the same intensity of support from the British government. But this change did not benefit Sinn Féin's propaganda work. De Valera, who escaped from prison on 3 February, praised Gavan Duffy's efforts on 27 August, declaring: "We are pleased to see that the efforts provided towards the French press are yielding results ${ }^{32}$ ", but a few days later, the Sinn Féin delegate again expressed his doubts on the level of interests of the French press for the Irish situation. In a report dated 10 September, he explained that without being "unfriendly", the attitude of the French periodicals seemed to be largely indifferent to the future of Ireland ${ }^{33}$.

Without experience, network or real means of pressure against Great Britain, this result had been predictable. But in spite of these difficulties, O'Kelly and Duffy continued to afford much importance to European public opinion. Understanding that European governments, especially the French government, were unlikely to put pressure on the British government in the diplomatic complex that followed the war, they developed the network of friends and journalist supporters which they lacked in 1919. While de Valera focused his diplomatic effort on the United States, work went on in Europe, with Paris as the main setting for the operations.

\section{Sinn Féin's diplomatic offensive}

21 It was not until 1920 that Gavan Duffy's policy started yielding results, even though his relations with the French political world remained very distant and cold. In a report dated 7 August 1920, for example, he observed: "French official circles are still preoccupied with the question of Ireland and Germany during the big war ${ }^{34}$." In fact, only one important political figure among Duffy's numerous correspondents can be named: the Catholic Christian Democrat deputy and future founder of the Parti démocrate populaire (Popular Democratic Party), Marc Sangnier ${ }^{35}$. He had been part of the reception committee during the visit of the Irish delegation in Paris in 1915, and his affection for the Irish nationalist cause was sincere. In spite of Sinn Féin's anti-allies policy during the war, he was the only deputy in the National Assembly Parliament on whom the Sinn Féin representatives could rely ${ }^{36}$. But Sangnier was not a newcomer, and Gavan Duffy continued to experience many difficulties in trying to diversify his political allies. Public opinion, always changeable and versatile, remained to be won over by active propaganda. became clear. On 1 March, Gavan Duffy received a long letter from Frédéric Causse-Maël. 
Largely forgotten nowadays, Causse-Maël (whose real name was Causse), was a soughtafter literary agent at the time. He published a few children's books and the translation of a text by Robert Louis Stevenson, The Night of the Islands for La Nouvelle Revue Française. He introduced himself to the Sinn Féin envoy as the co-director of the Agence littéraire française. Clearly the two men had met the day before this letter was sent. Causse-Maël outlined in six points the stages through which the Irish cause could achieve a level of recognition among the French press. He offered a "sustained effort in society" which "would soon garner interest for your cause from politicians and intellectuals whose influence is real". He also suggested co-operating with an information agency, which "would slip into the sheets sent to the newspapers the telegrams the most likely to revert or eradicate the influence of the English press. ${ }^{37}$ Thus the objective was to infiltrate Parisian intellectual and cultural circles, in order to influence public opinion and, if possible, various political circles. To ascertain Causse-Maël's reliability, Gavan Duffy procured some information from Maurice Bourgeois, a long-time friend of the Irish cause, a literary critic, translator and a specialist on the Irish literary revival. He was the author of a work written in English on John Millington Synge ${ }^{38}$ and the translator of several of his plays. It is worth noting for further research that Maurice Bourgeois' close connections with Ireland continued after the signing of the Anglo-Irish treaty, as he rendered his services as a translator for the Irish diplomatic delegates on a number of occasions in $1923^{39}$. Maurice Bourgeois reassured Gavan Duffy and affirmed that CausseMaël "has the machinery to help you" ${ }^{40 "}$.

23 At the same time important propaganda work was being done vis-à-vis several Parisian newspapers. As early as May 1920, Gavan Duffy noted: "All the French correspondents were quite friendly - except perhaps for the Temps ${ }^{41}$." This task was carried out simultaneously with propaganda from Ireland itself. The republican Desmond FitzGerald, chief of publicity, was responsible for maintaining good relations with foreign correspondents based in London. He obtained some significant results and explained the necessity to Duffy of putting into practice an eternal obsession of Irish nationalists: to "educate" European journalists about Irish realities ${ }^{42}$. On the same day, Duffy sent a report to FitzGerald, celebrating the progress made with the French press; possibly a direct consequence of the agreement reached with Causse-Maël:

The French campaign is so much bigger [...] I felt sure that it would not be long before the French press generally opened its columns wide to us, in self-defence against England [...] we were beyond the pale; but opinion is moving. "L'éclair" also wants to send a correspondent of its own at our expense to Dublin ${ }^{43}$.

L'éclair was a particularly Anglophobic periodical which developed important relations with the Vatican from 1914 onwards. Considering this, there is nothing surprising about the newspaper's sympathy with Irish independence. Nevertheless, and in spite of the enthusiasm of his letter, Gavan Duffy did not seem to be interested in working further with the newspaper. This attitude shows the new orientation that Gavan Duffy wanted to give to Irish propaganda in France, but also its limits. The Sinn Féin delegate no longer sought the help of conservative right-wing newspapers, traditional supporters of Irish nationalists. He was attempting to reach moderate good standard newspapers that were closer to the centre of French political stage, such as Le Temps or Le Journal des Débats. Le Temps continued to be a particular objective. In his letter to FitzGerald, Gavan Duffy explained his position thus: "We urgently want a correspondent from Le Temps in Dublin ${ }^{44}$ ." It was respectability that Gavan Duffy was hoping to obtain. 

perspective of the way in which it was portrayed in an increasingly violent Irish context. From November 1919, Desmond FitzGerald published the Irish Bulletin, a small periodical whose purpose was to fulfil what Fitzgerald described to Duffy as the "education" of foreign journalists. This small periodical could not aspire to provide a counterweight to the various press agencies, but some journalists used it to obtain "the other side" of the story. It was sent to New York and Paris in particular. For that reason, it contained a number of references clearly aimed at the French press. Thus in the issue of 30 March 1920: "Ireland was treated in a worse way by the English occupation troops than were Belgium or the north of France by the Kaiser's troops ${ }^{45}$." policy implemented by Gavan Duffy in France. This was the case for the Freeman's Journal and the Independent. The Freeman progressively gave up its allegiance to the Parliamentary Party, becoming more and more selective in its condemnation of political violence, approving for paramilitaries what it denounced for British forces. The radicalisation of both newspapers was expressed by the way they promoted Duffy's strategies to develop friendlier relations with France. On 7 July 1920, an enthusiastic report of a public meeting in which Marc Sangnier took part was published. The first sentences help to describe the state of mind of the paper:

It was thrilling to read the challenge on the walls of Paris this week. On the walls of Paris where, a while ago, the Peace Conference "made the world free" - with reservations ${ }^{46}$ !

Not omitting the fact that the Peace conference had given no space to Ireland, the Freeman relished the renewal of the Irish cause in Paris, giving the impression that the whole French capital was covered with posters promoting an independent Ireland. The article's rhetoric, very sympathetic towards France and its capital, may also be ascribed to its author, Daniel Laurence Kelleher, a playwright associated with the "Cork realist" movement. He had also written a work on Paris published in 1914 and entitled Paris, Its Glamour and Life. Kelleher concluded with a transcription of Marc Sangnier's speech, in which he dealt with one of the main objections to the warming up of the Franco-Irish friendship: the links Irish republicans had had with Germany during the war: "As for those who called the Irish pro-German, they could not make a greater mistake. Ireland was not pro-German but pro-Irish ${ }^{47}$." Sangnier took up a typical Sinn Féin argument used many times by anti-allies newspapers. The Freeman was not the only one to promote the work carried out by the Paris office. The Irish Independent stated on 3 January 1920:

French sympathy with Ireland is centuries old, but it is only quite recently that Frenchmen began to understand the Irish question [...] numerous French writers have somehow obtained first-hand information as to the position in Ireland ${ }^{48}$.

These two newspapers provided Gavan Duffy with the justification and recognition necessary to the continuation of his work in good conditions. This atmosphere of sweet optimism which oozed from the Irish press was so widespread and Duffy's reports on the evolution of his work in Paris were so positive, that on 31 August 1920 he received a letter offering him an increase of his staff ${ }^{49}$. But how pragmatic were these reactions?

The propaganda operations organized by Duffy understandably aroused the interest, the suspicion and the uneasiness of the French authorities, who were trying to prepare themselves for the increasingly realistic possibility of having to open official diplomatic relations with an independent Irish state without offending English sensibilities. In this 
context, Duffy was starting to become an embarrassment. At the beginning of September 1920, he was finally asked to leave French territory. The occasion for this action was a letter sent to the French president by Duffy in which he outlined the conditions under which Terence MacSwiney was being kept during his hunger strike, and asked the president to intervene. Duffy was first sent to Belgium and then to Rome where he was allowed to stay. The event is well known and documented. Nevertheless, it would be wrong to think that this constituted a major blow to Irish diplomacy in Paris. As we have seen above, most of the effort was concentrated on propaganda and on the media, very much a world without borders. The fact that Duffy had to leave France did not necessarily mean the end of the Irish propaganda effort in France, nor the end of Duffy's work, as he remained very active and continued to travel throughout Europe. Moreover, this move by the French government could have increased the sympathy of French opinion for the cause of Irish independence by giving Sinn Féin's representatives the status of victims of governmental and British oppression. Be that as it may, this decision did not imply the end of diverse diplomatic contacts between France and the representatives of Sinn Féin. Duffy had just about unpacked his bags in Rome when the French government contacted o'Kelly to ask him to define Ireland's position towards France, especially on economic and cultural issues. In a report sent to Diarmuid O'Hegarty on 9 November, O'Kelly insisted heavily on the necessity of making the French authorities understand the willingness of the future Irish government to have intensive trade relations with France. Among other things he explained: "[We] should clearly show the French government how it would be in its interest to have close and unhindered trade relations with Ireland ${ }^{50}$." The French representatives also attached much importance to Sinn Féin's ideological tendencies and its imagined links with bolshevist Russia. O'Kelly confirmed that "all the high authorities here are particularly concerned [with] the possibility of an evolution [of Sinn Féin's ideology] according to the bolshevist principles ${ }^{51}$ ".

For the most part, Sinn Féin was rather hostile to socialist ideals, and most of its representatives gave little importance to the workers' movement. However, several French socialists identified themselves with the Irish nationalist struggle. This tendency was shared by all the European left wing. The Soviet Union rapidly took an interest in Ireland's clandestine government and sent delegates to meet Eamon de Valera in 1920. This was sufficient to alarm the French government. Before his expulsion from France, Gavan Duffy had already warned of the consequences of such talks in a report to Desmond FitzGerald:

I saw with alarm that the President recommends an envoy being sent to Russia and I hope this step will not be taken without consideration; if it is taken, we may as well at once give up all further political effort on the Continent. I do not in the least want to thrust my personal opinions on those concerned, but I refer to this because I know what the effect will be in France ${ }^{52}$.

31 In 1920, the future certainly looked brighter than a year before. In fact, Sinn Féin's diplomatic efforts started to spread all over Europe. O'Kelly embarked on missions with Vatican delegates in Paris, and met Mussolini in Fiume to agree on a sale of arms which eventually failed. Moreover, the Italian parliament manifested some support for the "martyrdom of Ireland". For his part, Gavan Duffy began a propaganda mission in Spain in $1921^{53}$. In 1922, while Ireland lapsed into civil war, he remembered this diplomatic effervescence with nostalgia: "No country started its international career with a better potential than ours after the war ${ }^{54}$." Nevertheless, according to Dermot Keogh, this reaction more than anything else responded to an "infectious optimism". Keogh has 
argued quite rightly that, compared to the British leaders, the Sinn Féiners did not have the necessary diplomatic weight to influence European chancelleries ${ }^{55}$. Moreover, when the Civil War broke out between anti-Treatyites and the Free State, the Irish diplomatic service abroad also became divided. Besides, on 25 February 1921, O'Kelly admitted that the reactions from the press and the opinion in France were still linked to the state of French relations with Great Britain. Still, it remained essential to the future of the embryonic Irish foreign service to insist on the progress already made and success yet to come. Thus the report ended on a note of optimism:

\begin{abstract}
Since George V's last visit to Paris, the press has been instructed to avoid the Irish question as much as possible, so as not to give offence to England. The press is always therefore very reticent on Irish subjects. It appears to me that before long the French press must be very willing to give us big publicity because it seems practically certain that relations between France and England are becoming more and more strained ${ }^{56}$.
\end{abstract}

In spite of a rather unrealistic understanding of the future of Franco-British relations and of the advance made by Irish propaganda in France, credit must be given to the tone of the reports which Gavan Duffy sent to Dublin throughout 1920 . He was a competent diplomat and propagandist, whose work had not been without effect. In the course of 1921, some French newspapers showed an increasingly pronounced support for Sinn Féin and the republicans. These still came from the same socialist or conservative nationalist circles, but at least Gavan Duffy had succeeded in strengthening their friendship.

On 5 October 1921, the writer and future member of the Académie Française, Pierre Benoit, contacted O'Kelly to let him know about the forthcoming release of his last novel, $L a$ Chaussée des Géants (The Giant's Causeway) ${ }^{57}$. Benoit was then only starting his career, but he quickly asserted himself as an intellectual close to the Catholic nationalist Maurras and his newspaper, the Action Française. The Revue Universelle, founded on 1 April 1920 by Jacques Bainville and Henri Massis, which could be considered a satellite of Maurras' newspaper, published La Chaussée des Géants in a serial form between October 1921 and March 1922. Pierre Benoit's support for Irish national demands was consistent with the thought of Catholic, conservative and nationalist circles since the end of the nineteenth century. For many of these men, Ireland was a traditional, rural and Catholic island that had escaped the perverse cosmopolitan amorality of industrialisation and urbanisation. Some ideological references strengthened the links, such as the image of Joan of Arc, the maiden warrior who freed France from the yoke of foreign troops.

On the other side of the political scene, the friendship of right-wing Catholic and conservative newspapers was complemented by support from socialist periodicals, particularly the communist L'Humanité and the more moderate Le Populaire, mouthpiece of the SFIO or French Section of the Workers' International, the ancestor of the Parti Socialiste. In December 1921, the latter still preferred the moderate camp and backed the solution of the Anglo-Irish Treaty, calling De Valera's attitude "dangerous and regrettable 58". This was not the case with L'Humanité. On 3 December, this newspaper explained regarding the partition of Ireland that the British government had given in to the pressure of unionists, and paid a tribute to the efforts of the "republican workers". It concluded on 7 December that there could be no "true peace under a capitalist regime ${ }^{59}$ ". Generally speaking, the European socialists did not back the treaty, considering that it was the result of the anti-republican effort of classes that benefited from British capitalism and were working against the only true nation: the Irish workers ${ }^{60}$. However, both dailies did agree to support the IRA's armed actions between 1919 and 1921. In 
November 1921, L'Humanite deemed the struggle of the Irish republican army "heroic ${ }^{61}$ ". On 14 February, Le Populaire featured the headline "The audacious attack of a train carrying soldiers ${ }^{62 "}$.

We could, of course, conclude by saying that it was from this relative failure characterised as it was by the French government's lack of enthusiasm toward the Ireland of Sinn Féin - that the first diplomatic relations in history between France and Ireland had to be established. Relative failure, because Gavan Duffy did succeed in mobilising some sections of French public opinion situated at both extremes of the French political landscape. The Sinn Féin delegation was partly successful with the French press from the moment the terms of the Versailles Treaty became known. Less concerned by geostrategic considerations, it could criticise the British, while the French government was not prepared to upset its relations with London to the point of no return. But the results of this diplomatic strategy are not what matter the most. Historians have generally recorded the little impact made by Irish diplomacy in Europe during the Irish revolution. However, this reality should not mask the fact that the Irish made serious efforts during the Peace conference and subsequently. Recent works, such as Aengus Nolan's biography of Joseph Walsh have tried to underline the importance of a coordinated Irish European diplomacy for the definition of the country's politics in the 1920s. To come back to the subject of this article, we can only be struck by the constant efforts which Sinn Féin leaders made to reach French public opinion and governmental circles while the IRA was multiplying ambushes in Ireland. Obtaining international recognition was one thing, ensuring that European opinion would pressurize British leaders was another - and one that mattered more. This attitude certainly shows that Irish separatists at the start of the twentieth century were far from defining themselves in a purely Anglo-Irish context. On the contrary, it was essential for them to find other sources of identification in order to assert Ireland in Europe and in the world. In this context, France and its republican tradition, victorious if ill-treated ally of Great Britain, was a great source of preoccupation, inspiration and hope for Sinn Féin leaders. Of course, the realities of international politics quickly caught up with men who still had insufficient means to measure up to British diplomatic power. Results were therefore scarce. However, it was seen by all as a first step towards independence. In fact, the years that followed were to prove how essential those first steps in the big world were to Ireland's definition and self-affirmation as an independent nation.

\section{NOTES}

1. See on this subject Pierre Ranger, "La France et les propagandes nationalistes irlandaises durant la Première Guerre mondiale", Études Irlandaises (34.1, 2010, p. 23-36). See also Jérôme aan de Wiel, The Irish Factor, 1899-1919; Ireland's strategic and diplomatic importance for foreign powers, Dublin, Irish Academic Press, 2008, republished in paperback, 2010. 
2. Kevin Myers and Patrick Casey have suggested the figure of 35,000, while the memorial at Islanbridge estimates the toll at 49,000. David Fitzpatrick calculated that about 25,000 soldiers born in Ireland were killed during the war.

3. David Fitzpatrick, The Two Irelands, Oxford, Oxford University Press, 1998, p. 44.

4. This appears very clearly when John Redmond explains: "It is a war for the defense of the sacred rights and liberties of small nations, and the respect and enlargement of the great principle of nationality. Involved in it is the fate of France, our kindred country, the chief nation of that powerful Celtic race to which we belong." The Weekly Freeman, 19/09/1914.

5. See for example an article of Alice Millingan's in Shan Van Vocht, 1/11/1897, entitled "The Two Celtic Nations", explaining: "we Irish [...] are warm admirers of France and French civilisation. We consider the glory of France the glory of our common Celtic race." See also the first issue of Maud Gonne's L'Irlande Libre, the newspaper she edited in France, 5/1897: "Dans ce titre, expression de notre espérance, nous plaçons tout le programme de nos revendications nationales; et c'est à la France, pays toujours si cher aux opprimés, que nous venons jeter ce cri de liberté. D’ailleurs ne sommes-nous pas Celtes aussi, fils de la même race, et notre sang n'a-t-il pas coulé maintes fois sur les mêmes champs de bataille, sous nos drapeaux alliés."

6. See for example the Weekly Freeman, on 8 August 1914: "The French Mobilisation / A million men ready today / Mobilisation is proceeding with remarkable smoothness. Frontier telegrams of the violation of territory and the occupation of Luxemburg are received here with calm and composure."

7. On 3 August 1914 the Belfast Evening Telegraph explained: "If we fail them, the cry of "perfidious Albion" will, and not without reason, be on the lips of every son of France."

8. Jérôme aan de Wiel, The Irish factor..., op. cit., p. 171.

9. Jérôme aan de Wiel, The Catholic Church in Ireland, 1914-1918, Dublin, Irish Academic Press, 2003, p. 135.

10. Jérome aan de Wiel, The Catholic Church..., p. 222. The recruitment statistics for the period from August 1914 and February 1916 nevertheless remain considerable, as around 95,143 Irishmen enlisted in the British armies, not counting those who enlisted from the United States or different parts of the Empire.

11. Speeches collected in: La délégation irlandaise à Paris 1915, Paris, 1915. "These ties of blood have been strengthened by the close association of your people and ours through centuries [...] The Irish Brigade lives in proud Irish memories as one of the bravest and best fighting forces the world ever saw."

12. La délégation irlandaise...

13. For example, an article appeared on 12 September 1915 on the good treatment meted out to Irish soldiers in France, especially from convents: "[The nuns] have been extremely kind to our troops; they bring us food, and provide us with lodgings and the nuns, especially, deserve everyone's thanks."

14. Nationality, Eire Ireland and the Irishman - among others - were all Griffith's newspapers, Young Ireland, Honesty or the Spark were either controlled by the IRB or received help from the organisation, the Hibernian was financed by the Irish-American Alliance. 
15. See for example this quote taken from Honesty (closely financed and controlled by the IRB) on 15 January 1916: "The French people have practically no regard for the sanctity of marriage, and the State of France has given its sanction and recognition to immorality by legally recognizing illegitimacy." The amorality of the allies demonstrated by their use of colonial troops was also denounced. Griffith especially mocked "the Senegalese and cannibal Helots" that were being passed for the great defenders of the "Christian civilization", Nationality, 24 July 1915. Jérôme aan de Wiel's recent book, The Irish Factor, 1899-1919 has also shown that anticlerical France was the target of several "Sinn Féin priests".

16. Marianne Elliott, Partners in Revolution, London, Yale University Press, 1982, p. 366.

17. Sophie Ollivier, "Presence and absence of Wolfe Tone during the centenary commemoration of the 1798 rebellion", in Laurence M. Geary (ed.), Rebellion and remembrance in modern Ireland, Dublin, Four Courts Press, 2001, p. 175-184: p. 175.

18. For more information see Pierre Ranger, La France vue d'Irlande, Rennes, Presses Universitaires de Rennes, 2011.

19. See for example: Honesty, 22/01/1916: "Here is this unfortunate country, with the invader in possession of its choicest territory, and a much hated invader he is. The men of France are sacrificing everything that is dear to them in an effort to drive out the detested enemy. And while they are doing this the deposed oligarchy that rules the country is fattening upon its miseries. This shows what kind of patriot an atheist usually is."

20. Eire-Ireland, 02/12/1914: "Two of the Dublin pro-English organs published a letter from Mr. George Bernard Shaw, Mr. Shaw informs them that Ireland owes a debt of gratitude to France, and should therefore fight for France - the fact that they would be fighting for England, the war being 95 parts England's war- does not count."

21. Honesty, 4/03/1916: "The Frenchman knows that since the beginning of the war there are more than 700,000 killed, and nearly 800,000 permanently disabled, when the British Empire counts hardly 130,000 killed."

22. Eire-Ireland, 13/11/1914: "There is a rather bitter feeling growing between the French and English soldiers in the field. The French think the English have not "played the game."

23. The Catholic Bulletin, March 1918: "The argument that these two provinces in the main belonged to France before 1870 is not very convincing in supporting the French claim, for cannot it be asserted that during a considerably longer period allegiance was turned eastward from the Rhine [...] Their disgust for anti-clerical France has, we are disposed to think, settled the matter for all time."

24. Michael Hopkinson, The Irish War of Independence, Dublin, Gill and MacMillan 2002, p. 41.

25. Margaret MacMillan, Peace Makers, London, John Murray, 2001, p. 66.

26. Margaret MacMillan, Peace Makers..., p. 19.

27. Mervyn O'Driscoll, Ireland, Germany and the Nazis, Dublin, Four Courts Press, 2004, p. 25.

28. André Tardieu, The Truth about the Treaty, Indianapolis, p.192. Available for consultation on [www.net.lib.byu.edu]. 
29. National Archives, Dublin (hereafter referred to as NA), George Gavan Duffy papers, private accessions 1125, Files 1 to 5 .

30. NA, George Gavan Duffy papers, Files 1 to 5 . For a thorough analysis of Irish, French, British, American and German sources regarding the negociations, see Jérôme aan de Wiel, The Irish Factor..., chapter 9. Regarding Ireland's diplomatic beginnings, see also Micheal Kennedy's excellent article, “Civil Servants cannot be Politicians': the professionalisation of the Irish Foreign Service, 1919-22", in Irish Studies on International Affairs, vol. 8, 1997.

31. AMAE, Political and commercial correspondence, Miscellaneous and economic matters, boxes 15 to 18 .

32. NA, Early 2, Foreign Affairs, Paris 1919-1923, box 138.

33. Ibid.

34. NA, George Gavan Duffy papers, Files 1 to 5 .

35. Marc Sangnier was a Christian Democrat, founder of the Sillon movement, whose doctrine would be condemned by Pope Pius X in 1912. He wanted to establish a democratic republic between the traditional left and right wings. In his opinion, Christianity was the moral foundation of democracy. In October 1905 he launched the Eveil démocratique and in 1912 created the league of the young republic which used the ideas of the Sillon.

36. NA, George Gavan Duffy papers, Files 1 to 5 .

37. NA, George Gavan Duffy papers, File 9. "Un effort mondain soutenu ne tarderait pas à intéresser à votre cause les hommes politiques et les intellectuels dont l'influence est réelle soit sur les destinées du pays, soit sur la masse. Ces gens-là que je puis toucher facilement ne demanderont qu'à venir, à voir, à écouter. Ce sera à nous de les convaincre [...] 2. Entente avec une agence de télégrammes; l'Agence Information par exemple. Subvention à déterminer pour que la dite agence glisse dans ses feuilles envoyées aux journaux les télégrammes les plus propres à balancer l'influence de la propagande anglaise."

38. It is John Millington Synge and the Irish Theatre, London, 1913.

39. See NA, Early 2, Foreign Affairs, Paris 1919-1923, box 138. A report dated 23 January 1923 also mentioned an article for the Revue de Genève which the Irish authorities ordered from Maurice Bourgeois.

40. NA, papers of George Gavan Duffy, File 9.

41. NA, papers of George Gavan Duffy, File 7.

42. Ibid. "The least we can do is in my opinion to educate the correspondents as we have tried to, provide them proved facts, show them how badly they have been informed by the official reports."

43. Idem.

44. Idem.

45. The Irish Bulletin, 30/03/1920.

46. Freeman's Journal, 7/07/1920.

47. Idem.

48. The Irish Independent, 3/01/1920.

49. N.A., George Gavan Duffy papers, File 9. 
50. Ibid., Early series 2, Foreign Affairs, Paris 1919-1920.

51. Ibid.

52. NA, George Gavan Duffy papers, File 7.

53. Dermot Keogh, “The Origins of the Irish Foreign Service in Europe”, Études Irlandaises, 7 (1982), p. 145-164 and pp. 152-155.

54. George Gavan Duffy quoted by Dermot Keogh, Ireland and Europe, 1919-1948, Dublin, 1988, p. 10.

55. Dermot Keogh, “The Origins of the Irish...”, p. 151.

56. NA, Early series 1, Foreign Affairs, box 9.

57. Ibid., Benoit notably is supposed to have told him: "I am more Sinn Féiner than yourself."

58. Le Populaire, December $16^{\text {th }} 1921$, p. 2.

59. L'Humanité, December $7^{\text {th }} 1921$, p. 1.

60. Richard English, “Socialism: Socialist Intellectuals and the Irish Revolution”, in Joost Augustejn (ed.), The Irish Revolution, 1913-1923, New York, 2002, 203-223: 205.

61. L'Humanité, November $4^{\text {th }} 1921$, p. 1.

62. Le Populaire, February $14^{\text {th }} 1921$, p. 1.

\section{ABSTRACTS}

In a Europe traumatised by four years of slaughter, Ireland began its war of independence, a conflict whose fate was to be decided within as much as outside of the country. In fact, while the belligerents at rest redrew parts of the map of the world, Ireland looked for international recognition and the development of a diplomacy, in the heart of the negotiations of the peace treaties. France, the host of the Peace Conference but placed in a difficult situation by Great Britain, focused a lot of the Sinn Féin envoys' attention, sent to Paris to represent the changing Ireland. Consequently, a considerable challenge awaited those men: the implementation of a pragmatic Irish diplomatic policy faced with the realities of the raison d'Etat.

Dans une Europe traumatisée par une saignée de quatre ans, l'Irlande entamait sa guerre d'indépendance. Un conflit dont le sort allait se jouer à l'intérieur comme à l'extérieur du pays. Car au moment où les belligérants au repos redessinaient une partie de la mappemonde, l'Irlande se cherchait une reconnaissance internationale et se construisait une diplomatie, au cœur de la négociation des traités de paix. La France, hôte de la Conférence de la Paix mais allié «maltraité » de la Grande-Bretagne, provoqua une attention particulière chez les délégués du Sinn Féin, envoyés à Paris pour représenter l'Irlande en devenir. Dès lors, un défi de taille attendait ces hommes : la mise en œuvre d'une politique diplomatique irlandaise pragmatique face aux réalités de la raison d'État. 
INDEX

Keywords: Sinn Féin, diplomacy, press, Franco-Irish relations

Mots-clés: Sinn Féin , presse, diplomatie, relations franco-irlandaises, Première Guerre mondiale

\section{AUTHOR}

PIERRE RANGER

Université Paris-Diderot / connecthistory.com 